\title{
Fine-scale habitat utilization by birds in an ancient oak (Quercus spp.) wood- pasture in southwestern Turkey
}

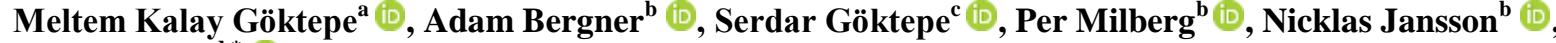 \\ Mustafa Avci ${ }^{\text {,"* }}$ (iD
}

\begin{abstract}
Wood-pastures are disappearing rapidly in the eastern Mediterranean basin due to changes in land use. Traditional farming by means of goat husbandry and pollarding has allowed many trees to become old, creating valuable habitats for biodiversity. Developing viable management schemes for habitats of conservation concern require studies aiming at identifying relationships between habitat structure and associated species. In this study, the associations between habitat structure and bird species diversity were studied on a fine scale, using data obtained from transect inventories in an oak wood-pasture in southwestern Turkey. Almost all species were most abundant where trunk size, basal area or tree density peaked. Diversity of ground-nesters was slightly and positively associated with an increase in basal area. Low canopy-nesters were positively associated with an increase in shrub density, whereas there was a negative association for high canopy-nesters. Secondary cavitynesters were unrelated to the density of small trunk cavities but exhibited a positive association with basal area of trees. Contrarily, primary cavity-nesters preferred trees with larger cavities, although this was most likely due to the presence of other desirable attributes of the very same trees. The results of this study give important insights to the structural and spatial organization of bird assemblages in a little studied but rich, culturally managed ecosystem in the Mediterranean.
\end{abstract}

Keywords: Assemblage, Conservation, Forest, Guilds, Management

\section{Güneybatı Türkiye'de yaşlı meşe ormanında (Quercus spp.) kuşların habitat kullanımı}

\begin{abstract}
Özet: Arazi kullanımındaki değişiklikler nedeniyle Doğu Akdeniz Havzası'nda yer alan mera niteliği de taşıyan ormanlar hızla yok olmaktadır. Geleneksel tarım ve hayvancılık faaliyetlerden keçi yetiştiriciliği ve yemlik dal yararlanması, bu sahalarda yer alan ağaçların yaşlanarak uzun yıllarca hayatta kalmasını sağlayarak biyolojik çeşitlilik için son derece değerli habitatlar yaratmıştır. Korunması gereken bu habitatlar için etkili ve uygulanabilir yönetim planlarının geliştirilmesi, habitat yapısı ve ona bağlı türler arasındaki ilişkileri tanımlamayı hedefleyen çalışmaları gerektirmektedir. Bu çalışmada, Türkiye'nin güneybatısında yer alan yaşlı bir meșe ormanında transekt yöntemi ile gerçekleștirilen habitat envanterlerinden elde edilen veriler kullanılarak, habitat yapısı ile kuş türü çeşitliliği arasındaki ilişkiler detaylı bir ölçekte ele alınmıştır. Genellikle sahada tespit edilen kuş türlerinin yoğunluğunun; ağacın gövde büyüklüğü, göğüs yüzeyi veya sıklığın artmasıyla doğru orantılı olduğu tespit edilmiştir. Yerde yuvalanan kuş türlerinin çeşitliliği üzerinde ağaçların göğüs yüzeyi artışı ile nispeten pozitif bir ilişkisinin olduğu tespit edilmiş; çalı ve ağaççı yoğunluğundaki artışın, alçak seviyelerde yuvalanan kuş türleri üzerinde olumlu, ancak yüksek seviyelerde yuvalanan kuş türleri açısından olumsuz bir etkisinin olduğu belirlenmiştir. Oyuk ve kovuklarda ikincil olarak yuvalanan kus türlerinin, küçük gövde oyuklarının yoğunluğu ile herhangi bir olumlu ya da olumsuz ilișkisine rastlanmazken, göğüs yüzeyi artışı ile olumlu bir ilişkisinin olduğu tespit edilmiştir. Bununla birlikte, oyuk ve kovuklarda birincil olarak yuvalanan kuş türlerinin daha büyük oyuklara sahip ağaçları tercih ettiği görülmüşsür. Ancak bu durum muhtemelen bu ağaçların diğer olumlu özelliklerinden de kaynaklanmış olabilir. Bu çalışmanın sonuçları, üzerinde az sayıda çalışma yapılmış ancak, tür çeşitliliğgi bakımndan zengin olan ve işletilen Akdeniz ekosistemlerindeki kuş topluluklarının yapısı ve dağı̆lımı hakkında önemli bilgiler vermektedir.
\end{abstract}

Anahtar kelimeler: Topluluk, Koruma, Orman, Birlik, Yönetim

\section{Introduction}

Birds are commonly used as indicators and model organisms to assess relationships between habitats and species, seeking to identify structures and resources to be highlighted in biological conservation and habitat management. For most species data are too scant to clarify relationships. Therefore, a common practice is to group species sharing similar ecological functions into ecological guilds and to analyse guild-wise data (e.g. Reinkensmeyer et al., 2007; Caprio et al., 2009; Mammides et al., 2015; Santamaría-Rivero et al., 2016). Such studies may be of a Eastern Mediterranean Forestry Research Institute, Tarsus, Turkey

b IFM Biology, Conservation Ecology Group, Linköping University, Linköping, Sweden

c Mustafa Baysan Vocational School of Higher Education, Mersin University, Mersin, Turkey

d Isparta University of Applied Sciences, Faculty of Forestry, Isparta, Turkey

@ * Corresponding author (İletișim yazarı): mustafaavci@isparta.edu.tr

$\checkmark \quad$ Received (Geliş tarihi): 13.11.2018, Accepted (Kabul tarihi): 21.03.2019
Citation (Atıf): Kalay Göktepe, M., Bergner, A. Göktepe, S., Milberg, P., Jansson, N., Avc1, M., 2019. Fine-scale habitat utilization by birds in an ancient oak (Quercus spp.) wood-pasture in southwestern Turkey. Turkish Journal of Forestry, 20(1): 1-7. DOI: $10.18182 /$ tjf. 482386 
significance where certain habitats have undergone recent decline, and where it is important to prioritize conservation efforts to develop viable management and maintain biodiversity. This scenario may be applied to most of the Mediterranean basin, where natural or near-natural habitats and entire landscapes have been heavily altered by man as a result of wildfires, overgrazing, exploitation and plantation forestry using non-native tree species (Thirgood, 1981; Bainbridge, 1985; Rackham and Moody, 1997; Kaniewski et al., 2007). Examples of habitats of significant concern are the ancient oak wood-pastures found in mountainous areas where traditional farming is still being practiced (Hartel and Plieninger, 2014; Schaich et al., 2015), for example in the Mediterranean part of southern Turkey (Bergner et al., 2016). In an economically improving country, many oak wood-pastures of former importance for rural communities are now at risk of being logged and transformed into coniferous plantations (Kaya and Raynal, 2001; Sama et al., 2011). The old oak habitats in Turkey have been shown to be significant habitats for birds (Bergner et al., 2015; Bergner et al., 2018) and also harbour an exceptionally rich saproxylic invertebrate fauna (e.g. Jansson and Coskun, 2008; Novak et al., 2011). Effective protection and management are crucial for the maintenance of the biodiversity associated with old oak habitats, but still there is a gap in knowledge of which habitat parameters determines community structure (Hartel et al., 2014). Regarding birds, previous research conducted in Mediterranean oak habitats have pointed to several factors positively related to bird species richness and community structure, including patch size (Frank and Battisti, 2005), stand age (Mentil et al., 2018), access to trunk cavities (Robles et al., 2011) and presence of scrub and understory vegetation (Camprodon and Brotons, 2006). Most studies have focused on assessing differences in bird species diversity and assembly among forest stands distributed over large spatial scales. Less information is available about how avian assemblages relate to habitat structure on a finer scale, e.g. within a habitat patch. The fine-scaled relationships observed in the field, however, are likely to be less clear as birds are mobile and many also territorial.

In the present study, we set out to describe relationships between habitat structure and bird assemblages using transect inventories on a large isolated hill consisting of a pasture with a varying density of trees (mainly oaks) and shrubs. We considered species as well as nesting guilds, i.e. guilds of species with similar nesting habitats or habits, and the following variables to describe the habitat: 1) density of shrubs, 2) density of trees, 3) basal area of trees, 4) average trunk diameter, 5) density of trees with small cavities, and 6) density of trees with large cavities.

\section{Material and methods}

\subsection{Study area}

The study was carried out in the cultivated plain lands located at the western range of the Turkish Taurus Mountains (Figure 1). The region has a typical continental climate with rainy winters and dry and hot summers. Mean annual precipitation is $508 \mathrm{~mm}$ (Turkish State Meteorological Service; http://www.mgm.gov.tr). The study area consists of a larger hill (area ca. 150 hectare; altitude 960-1020 m.a.s.l.) overlooking the eastern shore of the lake
Eğirdir. The hill is covered with mixed stands of oak (predominantly Quercus ithaburensis and to a smaller extent $Q$. infectoria while $Q$. coccifera is the most dominant shrub) including both old hollow trees formerly utilized for pollarding as well as younger trees more recently coppiced. The area is currently heavily grazed by domestic goats.

\subsection{Bird surveys}

Birds were surveyed during the first three hours after sunrise between April 13-23, 2015 using line transect counts (Gregory et al., 2004). Eighteen line transects (150 m to $775 \mathrm{~m}$ in length) were created, covering most of the oak habitats on the hill. The lengths of each transect were determined by the consistency of the vegetation structure. A new transect started when the vegetation structure clearly changed and remained as long as the vegetation was similar to the beginning of the transect. Transects were located at least $120 \mathrm{~m}$ apart from each other to avoid counting any bird more than once. To track transects and measure their individual lengths, a range finder (Garmin Etrex Vista) was used. During the surveys, all birds seen or heard within a distance of $50 \mathrm{~m}$ from each transect were noted. Surveys were conducted by one observer to limit the risk of observer bias, and not conducted on rainy and windy days since it may negatively influence bird detectability (Sutherland, 2006). At the end of surveys, data on bird abundance of each transect were recalculated into numbers as the density of territories per hectare.

We used five nesting guilds (High-canopy nesters (abbreviated HCN i Table 1), Low canopy-nesters (LCN), Ground-nesters (GN), Primary cavity-nesters (PCN) and Secondary cavity-nesters (SCN)), and data on Cuculus canorus were discarded, which did not belong to any of these guilds. For each transect, the density of the guilds represented the mean density of all species included within each guild.

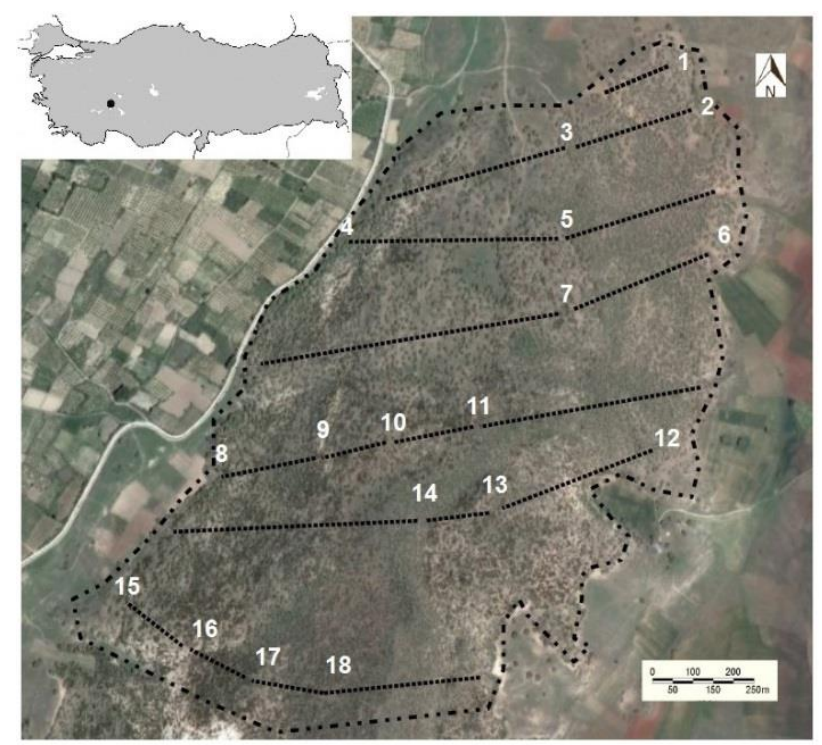

Figure 1. The position of the study site in southwestern Turkey (recessed) and the hill with all transects deployed. 


\subsection{Sampling of environmental variables}

Within $5 \mathrm{~m}$ on both sides of each transect the following six parameters were sampled:

(1) The structure of understory vegetation (shrubs and small trees $\leq 2 \mathrm{~m}$ in height), henceforth denoted shrub density. The shrub density was estimated every $20 \mathrm{~m}$ in a $10 \mathrm{~m}$ wide band along each transect by using a handheld wooden frame and estimate (in \%/100) the proportion of the eyesight that was covered by shrubs.

(2) The density of trees per hectare was calculated by counting all trees within a $50 \mathrm{~m}$ wide band on each side of transects.

(3) Basal area of individual trunks was calculated from the diameter at breast height (DBH) using a caliper. An average basal area per transect was calculated and used in the analyses.

(4) Trunk diameter was measured at breast height (approximately $130 \mathrm{~cm}$ above ground) using a caliper. This was then recalculated to average trunk diameter per transect.

(5) The density of small trunk cavities (class 1-2 in Figure 2) and (6) large trunk cavities (class 3-4 in Figure 2), derived from the number of trees having small and large cavities, respectively. For each transect these numbers were then recalculated into average number of trees with small and large cavities per hectare.

\subsection{Data analysis}

We analysed how the density of territories per guild could be explained by the explanatory variables listed above using generalized linear models (GLM; STATISTICA 13). More specifically, we conducted all possible combinations of the explanatory variables in GLMs, then selected the most economic model, i.e. considering both the model's explanatory power and the number of explanatory variables used, using the the Akaike information criteria (AIC).

The species-wise data were evaluated with multivariate analysis, using the CANOCO 5 software (Ter Braak and Šmilauer, 2012). The Principal Component Analysis (PCA) was chosen, because of relatively low beta-diversity, and the six explanatory variables were used as supplementary variables. This means that the solution is driven only by species-composition while the six other variables are added to facilitate interpretation. To confirm that the patterns identified were meaningful, we also conducted a Stepwise Forward RDA (redundancy analysis). This analysis considered only the part of composition data that one or more explanatory variables can account for; by permuting the variable(s), it is also possible to assess the statistical significane of variable(s).

\section{Results}

Along the 18 transects, a total number of 355 bird territories belonging to 27 species (Table 1) were identified.

The variation in density of trees and density of hollow trees varied ten-fold among transects, while shrub density and trunk diameter varied five-fold, and slightly less in basal area (Table 2).
Table 1. The bird species included in the study and the nesting-guild category for each species. $\mathrm{HCN}=$ Highcanopy nesters; LCN = Low-canopy nesters; SCN = Secondary cavity-nesters; PCN = Primary cavity-nesters; $\mathrm{GN}=$ Ground-nesters .

\begin{tabular}{lc}
\hline Scientific name & Guild category \\
\hline Accipiter nisus & HCN \\
Streptopelia decaocto & LCN \\
Cuculus canorus & none \\
Athene noctua & SCN \\
Upupa epops & SCN \\
Dendrocopus syriacus & PCN \\
Lullula arborea & GN \\
Luscinia megarynchos & GN \\
Turdus viscivorus & HCN \\
Turdus merula & LCN \\
Sylvia curruca & LCN \\
Phylloscopus orientalis & GN \\
Parus major & SCN \\
Cyanistes caeruleus & SCN \\
Poecile lugubris & SCN \\
Aegithalos caudatus & LCN \\
Garullus glandarius & LCN \\
Sturnus vulgaris & SCN \\
Fringilla coelebs & LCN \\
Linaria cannabina & LCN \\
Carduelis carduelis & HCN \\
Chloris chloris & LCN \\
Serinus serinus & LCN \\
Emberiza caesia & GN \\
Emberiza cirlus & GN \\
\hline
\end{tabular}

Table 2. Description of environmental variables describing 18 transects in the oak wood-pasture.

\begin{tabular}{lrrrr}
\hline & Average & SD & Min & Max \\
\hline Density of shrub (\%/100) & 0.38 & 0.21 & 0.10 & 0.80 \\
Density of trees $\left(\mathrm{ha}^{-1}\right)$ & 214 & 134 & 57 & 441 \\
Basal area $\left(\mathrm{m}^{2} \mathrm{ha}^{-1}\right)$ & 10.8 & 3.5 & 5.3 & 17.9 \\
Mean trunk diameter $(\mathrm{cm})$ & 27.5 & 12.3 & 14.0 & 55.1 \\
Density of trees with small cavities $\left(\mathrm{ha}^{-1}\right)$ & 17.3 & 11.4 & 4.7 & 46.7 \\
Density of trees with large cavities (ha-1) & 10.0 & 6.0 & 0.0 & 23.1 \\
\hline
\end{tabular}

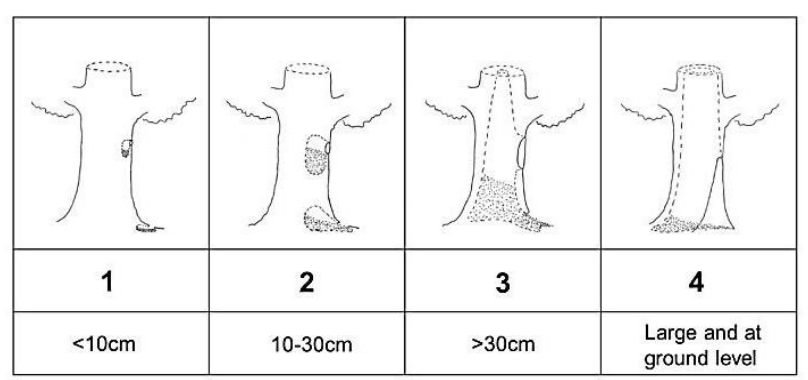

Figure 2. The model used for classification of cavity stages (1-4), following Jansson and Antonsson (2002). Entrance of cavity's diameter states the stage.

\subsection{Bird-habitat associations at guild-level}

The GLM failed to identify a significant model for ground-nesters and primary cavity-nesters, the latter possibly due to their low numbers in the data and hence, low statistical power (Table 3). Density of secondary cavitynesters increased with basal area while low-canopy nesters increased with shrub density (Table 3 ). In contrast, highcanopy nesters decreased with shrub density (Table 3 ). 
Table 3. Summary of GLM (normal distribution, identity link) pf guild-wise data. The best models selected contained one or two explanatory variables; these are indicated as + or - depending on whether it had a positive or negative effect; if the sign is within parenthesis then the partial regression coefficient is NS (P >0.05).

\begin{tabular}{|c|c|c|c|c|c|c|}
\hline & Model P-value & Tree density & Basal area & Small cavities & Large cavities & Shrub density \\
\hline Ground nesters & NS 0.11 & & $(+)$ & & & \\
\hline Primary cavity-nesters & NS 0.07 & & & & $(+)$ & \\
\hline Secondary cavity-nesters & 0.0049 & & + & & $(-)$ & \\
\hline Low-canopy nesters & 0.0173 & & $(-)$ & & & + \\
\hline High-canopy nesters & 0.0050 & & & & $(+)$ & - \\
\hline
\end{tabular}

\subsection{Bird-habitat associations at species-level}

In the species-composition analyses, smaller trees and less timber meant fewer species (Figure 3a), in fact almost all species were most abundant where trunk size, basal area or tree density peaked (Figure 3b). About one third of the species peaked when trunk size was high (Figure 3b). Furthermore, half a dozen species were most abundant in transects with high tree density (but low trunk size, hence dense, younger stands; Figure 3b). Density of small cavities seemed a less important attribute while basal area was - as expected - intermediate between tree density and trunk size (the two latter define the basal area; Figure 3b). Among the strongest species/environment associations were Sylvia curruca and shrub density, Fringilla coelebs and tree density, Dendrocopos syriacus and large cavities and Carduelis carduelis and basal area (Figure 3b). The density of trees with small cavities seemed unrelated to species composition while density of trees with large cavities was slightly positive for both primary cavity-nesters as well as high canopy-nesters. On the other hand, there was a tendency for secondary cavity-nester species to be related to the density of large cavities.

The RDA with forward selection resulted in a model with two significant, explanatory variables: Basal area and Tree density.

\section{Discussion}

Grazing by domestic goats have been intense in the study are for a long time. This management regime has created a semi-open, oak-dominated wood-pasture with a field layer of grasses, herbs and a mosaic of shrubs. The study area is not homogenous in terms of structure but contain patches dominated by a few larger trees interspersed with shrubs as well as patches that are more forested with a larger density of younger trees. Open habitats with a low density of trees may potentially offer few suitable nest sites for ground-nesting birds. While birds nesting in open grazed grasslands may be negatively influenced by the presence of trees and shrubs, thus generally place their nests concealed in taller vegetation (Davis, 2005), the relationship between ground-nesters and vegetation structure in semi-open woodpastures is little described. Our study suggests that groundnesters may benefit from an increase in basal area of tree trunks. Where the basal area of woody vegetation is more abundant the influences by grazing animals may be somewhat obstructed by physical constraints. Thus, there is a possibility that many ground-nesters in the study area prefer to place their nests in proximity to trees since it help reduce the risk of stomped nests or even predation. Pereira et al., (2014) showed that, in heavily grazed montado systems in Portugal, the guild of leaf-warblers (including Western Bonelli's Warbler Phylloscopus bonelli) decreased with an increase in forest management which included removal of understory vegetation. Western Bonelli's Warbler, a ground-nester, may benefit from retained shrubs in the semi-open structure of grazed oak woodlands similarly to ground-nesters in Turkish oak woodlands.
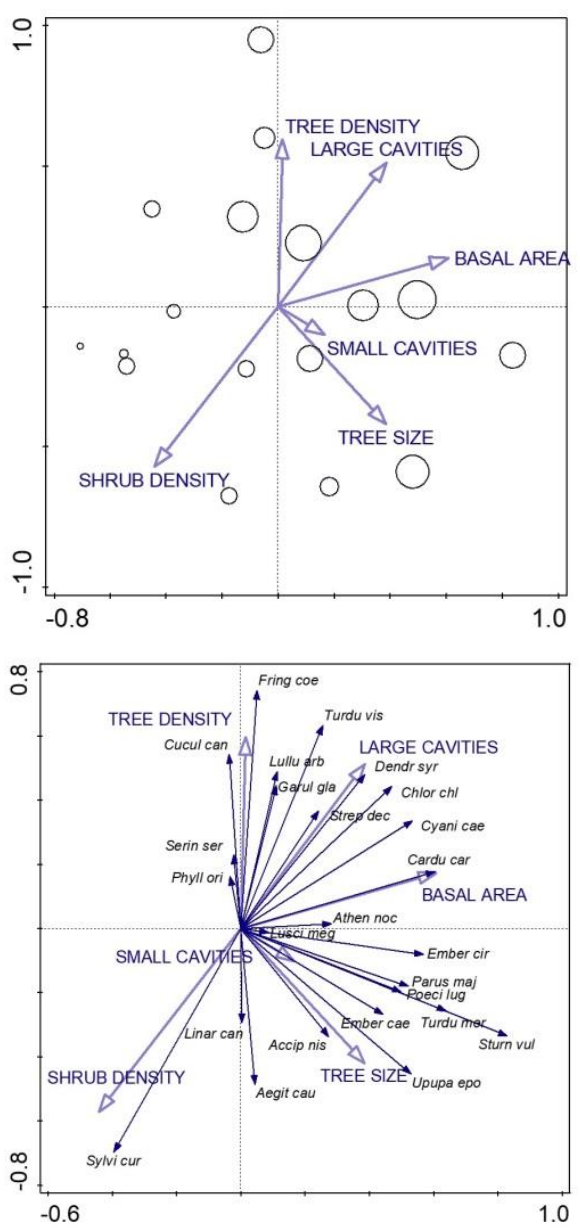

Figure 3. PCA of bird data from the 18 transects in the wood-pasture. Passive explanatory environmental variables added. 3a) Sites and explanatory variables, size of the circle proportional to number of species recorded in transect; $3 \mathrm{~b}$ ) Species and explanatory variables. 
Overall, there was a positive association between the density of forested vegetation and the number of bird species. This is somewhat unexpected results that deviate from findings in previously conducted studies within the same Turkish province (Bergner et al., 2015), but similar to results from e.g. Spanish Catalonia (Gil-Tena et al., 2007). In the latter study, however, they found a lower number of species in forests of higher canopy closure, suggesting that there is a threshold in the association between forest density and bird species richness. Since the study area is heavily grazed and have a long history of both pollarding and coppicing creating a rather semi-open forest, the vegetation structure may only cover a minor gradient, thus resulting in less prominent associations. Except for a few species, the factor "tree density" was not a clear predictor for any of the guilds. Instead, shrub density and to some extent basal area of tree trunks were better explanatory variables for some of the guilds. Low-canopy nesters were positively associated with shrub density whereas high-canopy nesters were negatively associated with shrub density. This is clearly an indication of differences in the utilization of the habitats between species belonging to the two guilds. While lowcanopy nesters, particularly songbirds of the genus Sylvia, are well adapted to vegetation in earlier stages of succession (Blondel and Farré, 1988) and benefit from retained shrubs in the forest understory (Camprodon and Brotons, 2006), the high-canopy nesters are more dependent upon developed forests with taller vegetation in order to find suitable nesting places.

Extrapolating the registered number of hollow oaks on the hill (in average 27 hollow trees per hectare) reveals an area offering an exceptionally large number of cavities. This means that there are plenty of potential nesting places for secondary cavity-nesting birds in particular. The relationship between cavity occurrence and density of cavity-nesting species, however, is less dependent upon the actual number of cavities but rather depend on the quality and suitability of the cavities as potential nesting places (Camprodon et al., 2008; Robles and Martin, 2013). The cavities in the study area varied in size, shape, height, and presumably in suitability as nesting cavities. We therefore grouped the hollow trees in two categories and tested their relationships on guilds and species independently. While several studies have suggested that the populations of secondary cavity-nesting birds are limited by a shortage of suitable cavities and that local cavity manipulations can enhance populations of these species (e.g. Newton, 1994a; Cockle et al., 2010; Robles et al., 2012; Segura, 2017, but cf Wiebe, 2011), our study failed to confirm these results. The secondary cavity-nesters did, however, exhibit a rather strong, albeit nonsignificant, negative relationship with the density of large hollows. This is likely due to the inability of large hollows to function as suitable nest sites for secondary cavity-nesting birds, particularly small passerines (e.g. Parus major and Cyanistes caeruleus) that dominate the guild. There was no clear relationship between the guild of secondary cavity-nesters and the density of small trunk cavities, which may be due to the approach for this study: presuming that there is a shortage in suitable cavities which acts as a limiting factor for the secondary cavity-nesters. This scenario is probably applicable for most forests subjected to any form of conventional management (e.g. Politi et al., 2010; Robles et al., 2011), but may be of less significance in forests that are not managed solely for the purpose of timber production. Considering the unique history of pollarding, a management that promotes the formation of cavities (Sebek et al., 2013), the study area may in fact offer more potential nesting cavities than there are cavity-nesters to occupy them (Waters et al., 1990; Bai et al., 2003; Wesołowski, 2007). Apart from nest avalability, there are other factors that potentially pose a limitation in the abundance of secondary cavity-nesters, such as predation, parasitism and food supply (Newton, 1994b; Newton, 1998; Nagy and Holmes, 2005). Furthermore, the density of trunk cavities, like other habitat variables, may also better explain bird assembly structure across larger spatial scales unrelated to distinct verges between habitats of different structure (e.g. Touihri et al., 2017).

Secondary cavity-nesters were positively related to the basal area of tree trunks, either by preferring densely forested habitats consisting of smaller trees or less densely forested habitats consisting of fewer but larger trees. Since there was no clear association with tree density we assume that larger trees represent a better predictor for the density of secondary cavity-nesters. Typically, larger trees exhibit a higher abundance of complex microhabitats, such as snags, dead wood and cavities (Regnery et al., 2013; Paillet et al., 2017) that may be desirable for secondary cavity-nesting species, not just for nesting but for e.g. foraging as well. Correspondingly, primary cavity-nesters are considered ecosystem engineers (Jones et al., 1994) since their processing of wood gives rise to structures and microhabitats that other organisms, including secondary cavity-nesters, depend on or benefit from (Martin and Eadie, 1999). Interestingly, we found a rather strong, albeit nonsignificant, positive relationship between the density of large cavities and the density of primary cavity-nesters. Since primary cavity-nesters generally manufacture their own nesting cavities this relationship is most likely indirect, suggesting that the very same trees that offer large cavities also offer other structures desired by primary cavity-nesters. Not all cavities used by secondary cavity-nesters are the work of primary cavity-nesters. For European conditions many cavities created by woodpeckers are typically shortlived (Cockle et al., 2011), why most available cavities rather originate from branch sheds and other types of mechanical injuries to the tree trunks (Remm et al., 2006). Still, while the creation of cavities from e.g. branch sheds is a slow process that may occur irregularly, the primary cavity-nesters annually create new cavities and thereby provide a useful source of cavities for other species, including secondary cavity-nesters. Furthermore, when such cavities are no longer suitable as nesting sites for birds they may provide important microhabitats for wood-living fungi, bats and saproxylic invertebrates.

\section{Conclusions and considerations for management}

This study demonstrates the significance of various habitat structures on bird assemblages on a fine scale. The use of this approach generates a narrower spatial resolution that may not necessarily be translatable to results from studies based on data sampled from several locations. However, it enables for careful analyses of the variation and associations in both habitat structure and bird assembly structure within a defined geographical area. In the current study area, the variables basal area and tree trunk density showed the highest explanatory power for bird assembly 
structure indicating that, for bird species diversity, it is important to maintain large trees and sufficiently dense forest habitats. In semi-open habitats that are being heavily grazed, retaining a certain amount of understory will benefit particularly low-canopy nesters, as well as ground-nesters that can find suitable nest sites concealed near shrubs and trees. Despite the large number of trunk cavities in the study area there were no clear relationships between cavity abundance and densities of secondary cavity-nesters. In contrast to conventionally managed forests, cavities suitable for nesting birds may not be a limiting factor in the study area. We conclude that different birds are dependent upon different structures and resources in their breeding territories, and that the habitat management reflect the bird assemblages on a finer scale. The results give important insights to the structural organization of bird assemblages and how different guilds or even species may be codependent upon various structures. This knowledge may be of significant interest for the development and targeting of more cost-effective and viable management methods of wood-pastures in the eastern Mediterranean.

\section{Acknowledgements}

We are grateful to Isparta Regional Directorate of Forestry for logistic support.

\section{References}

Bai, M-L., Wichmann, F., Mühlenberg, M., 2003. The abundance of tree holes and their utilization by hole-nesting birds in a primeval boreal forest in Mongolia. Acta Ornithologica, 38: 95-102.

Bainbridge, D.A., 1985. The rise of agriculture: a new perspective. Ambio, 14: 148-151.

Bergner, A., Avcı, M., Eryiğit, H., Jansson, N., Niklasson, M., Westerberg, L., Milberg, P., 2015. Influences of forest type and habitat structure on bird assemblages of oak (Quercus spp.) and pine (Pinus spp.) stands in southwestern Turkey. Forest Ecology and Management, 336: 137-147.

Bergner, A., Sunnergren, A., Yeşilbudak, B., Erdem, C., Jansson, N., 2016. Attributes of trees used by nesting and foraging woodpeckers (Aves: Picidae) in an area with old pollarded Oaks (Quercus spp.) in the Taurus Mountains, Turkey. Zoology in the Middle East, 62: 288-298.

Bergner, A., Türkay, O.Ç., Eryiğit, H., Avc1, M., 2018. Overview of the bird diversity in oak (Quercus spp.) forest habitats in Isparta province, southwestern Turkish Anatolia. Turkish Journal of Forestry, 19: 347-354.

Blondel, J., Farré, H., 1988. The convergent trajectories of bird communities along ecological successions in European forests. Oecologia, 75: 83-93.

Camprodon, J., Brotons, L., 2006. Effects of undergrowth clearing on the bird communities of the Northwestern Mediterranean Coppice Holm Oak forests. Forest Ecology and Management, 221: 72-82.

Camprodon, J., Salvanyà, J., Soler-Zurita, J., 2008. The abundance and suitability of tree cavities and their impact on hole-nesting bird populations in beech forests of NE Iberian Peninsula. Acta Ornithologica, 43: 17-31.

Caprio, E., Ellena, I., Rolando, A., 2009. Assessing habitat/landscape predictors of bird diversity in managed deciduous forests: a seasonal and guild-based approach. Biodiversity and Conservation, 18: 1287-1303.

Cockle, K.L., Martin, K., Drever, M.C., 2010. Supply of tree-holes limits nest density of cavity-nesting birds in primary and logged subtropical Atlantic Forest. Biological Conservation, 143: 2851-2857.
Cockle, K.L., Martin, K., Wesołowski, T., 2011. Woodpeckers, decay, and the future of cavity-nesting vertebrate communities worldwide. Frontiers in Ecology and the Environment, 9: 377382.

Davis, S.K., 2005. Nest-site selection patterns and the influence of vegetation on nest survival of mixed-grass prairie passerines. The Condor, 107: 605-616.

Díaz, L., 2006. Influences of forest type and forest structure on bird communities in oak and pine woodlands in Spain. Forest Ecology and Management, 223: 54-65.

Frank, B., Battisti, C., 2005. Area effect on bird communities, guilds and species in a highly fragmented forest landscape of central Italy. Italian Journal of Zoology, 72: 297-304.

Gil-Tena, A., Saura, S., Brotons, L., 2007. Effects of forest composition and structure on bird species richness in a Mediterranean context: implications for forest ecosystem management. Forest Ecology and Management, 242: 470-476.

Gregory, R.D., Gibbons, D.W., Donald, P.F. Bird census and survey techniques. In Sutherland et al., 2004. Bird ecology and conservation $-\mathrm{a}$ handbook of techniques.

Hartel, T., Hanspach, J., Abson, D.J., Máthé, O., Ioan Moga, C., Fischer, J., 2014. Bird communities in traditional woodpastures with changing management in Eastern Europe. Basic and Applied Ecology, 15: 385-395.

Hartel, T., Plieninger, T. (eds)., 2014. European wood-pastures in transition: A social-ecological approach. Routledge, New York.

Jansson, N., Antonsson, K., 2002. The work with old trees and saproxylic beetles in Östergötland, Sweden. In: Bowen, C. P. N. (eds). Conservation of saproxylic beetles in ancient trees, with special attention to the stag beetle Lucanus cervus, violet click beetle Limoniscus violaceus, noble chafer Gnorimus nobilis and variable chafer Gnorimus variabilis. People's Trust For Endangered Species, Royal Holloway, University of London, pp. 41-43.

Jansson, N., Coskun, M., 2008. How similar is the saproxylic beetle fauna on old oaks (Quercus spp.) in Turkey and Sweden? Revue d'Écologie (Terre Vie) suppl. 10: 91-99.

Jones, C.G., Lawton, J.H., Schachak, M., 1994. Organisms as ecosystem engineers. Oikos, 69: 373-386.

Kaniewski, D., de Laet, V., Paulissen, E., Waelkens, M., 2007. Long-term effects of human impact on mountainous ecosystems, western Taurus Mountains, Turkey. Journal of Biogeography, 34: 1975-1997.

Mammides, C., Schleuning, M., Böhning-Gaese, K., Schaab, G., Farwig, N., Kadis, C., Coulson, T., 2015. The indirect effects of habitat disturbance on the bird communities in a tropical African forest. Biodiversity and Conservation, 24: 3083-3107.

Martin, K., Eadie, J.M., 1999. Nest webs: A community-wide approach to the management and conservation of cavitynesting forest birds. Forest Ecology and Management, 115: 243-257.

Mentil, L., Battisti, C., Carpaneto, G.M., 2018. The older the richer: significant increase in breeding bird diversity along an age gradient of different coppiced woods. Web Ecology, 18: 143-151.

Nagy, L.R., Holmes, R.T., 2005. Food limits annual fecundity of a migratory songbird: an experimental study. Ecology, 86: 675681.

Newton, I., 1994a. The role of nest sites in limiting the numbers of hole-nesting birds: a review. Biological Conservation, 70: 265276.

Newton, I., 1994b. Experiments on the limitation of bird breeding densities: a review. Ibis, 136: 397-411.

Newton, I., 1998. Population limitations in birds. Academic Press Limited.

Novak, V., Jansson, N., Avcı, M., Sarıkaya, O., Coşkun, M., Atay, E., \& Gürkan, T., 2011. New Allecula species (Coleoptera: Tenebrionidae: Alleculinae) from Turkey. Journal of the Entomological Research Society. Studies and reports. Taxonomical Series, 7: 335-346. 
Paillet, Y., Archaux, F., Boulanger, V., Debaive, N., Fuhr, M., Gilg, O., Gosselin, F., Guilbert, E., 2017. Snags and large trees drive higher tree microhabitat densities in strict forest reserves. Forest Ecology and Management, 389: 176-186.

Pereira, P., Godinho, C., Roque, I., Marques, A., Branco, M., Rabaça, J.E., 2014. Time to rethink the management intensity in a Mediterranean oak woodland: the response of insectivorous birds and leaf-chewing defoliators as key groups in the forest ecosystem. Annals of Forest Science, 71: 25-32.

Politi, N., Hunter, Jr M., Rivera, L., 2010. Availability of cavities for avian cavity nesters in selectively logged subtropical montane forests of the Andes. Forest Ecology and Management, 260: 893-906.

Rackham, O., Moody, J., 1997. The Making of the Cretan Landscape. Manchester University Press.

Regnery, B., Covet, D., Kubarek, L., Julien, J-F., Kerbiriou, C., 2013. Tree microhabitats as indicators of bird and bat communities in Mediterranean forests. Ecological Indicators, 34: 221-230.

Reinkensmeyer, D.P., Miller, R.F., Anthony, R.G., Marr, V.E., 2007. Avian community structure along a mountain big sagebrush successional gradient. The Journal of Wildlife Management, 4: 1057-1066.

Remm, J., Lõhmus, A., Remm, K., 2006. Tree cavities in riverine forests: what determines their occurrence and use by holenesting passerines? Forest Ecology and Management, 221: 267-277.

Robles, H., Ciudad, C., Matthysen, E., 2011. Tree-cavity occurrence, cavity occupation and reproductive performance of secondary cavity-nesting birds in oak forests: the role of traditional management practices. Forest Ecology and Management, 261: 1428-1435.

Robles, H., Ciudad, C., Matthysen, E., 2012. Responses to experimental reduction and increase of cavities by a secondary cavity-nesting bird community in cavity-rich Pyrenean oak forests. Forest Ecology and Management, 277: 46-53.

Robles, H., Martin, K., 2013. Resource quantity and quality determine the interspecific associations between ecosystem engineers and resource users in a cavity-nest web. PLoS ONE, 8(9): e74694. https://doi.org/10.1371/journal.pone.0074694.

Sama, G., Jansson, N., Avc1, M., Sarikaya, O., Coskun, M., Kayis, T., Özdikmen, H., 2011. Preliminary report on a survey of the saproxylic beetle fauna living on old hollow oaks (Quercus spp.) and oak wood in Turkey. Munis Entomology and Zoology, 6: 819-831.
Santamaría-Rivero, W., Leyequién, E., Hernández-Stefanoni, J.L., Wood, P., 2016. Influence of landscape structure and forest age on the richness and abundance of different bird feeding guilds and forest-dependent birds in a seasonal dry tropical forest of Yucatan, Mexico. Tropical Ecology, 57: 313-332.

Schaich, H., Kizos, T., Schneider, S., Plieninger, T., 2015. Land change in Eastern Mediterranean wood-pasture landscapes: the case of deciduous oak woodlands in Lesvos (Greece). Environmental Management, 56: 110-126.

Sebek, P., Altman, J., Platek, M., Cizek, L., 2013. Is active management the key to the conservation of saproxylic biodiversity? Pollarding promotes the formation of tree hollows. PLoS ONE, 8(3): e60456. https://doi.org/10.1371/journal.pone.0060456.

Segura, A., 2017. How does vegetation structure influence woodpeckers and secondary cavity nesting birds in African cork oak forest? Acta Oecologica, 83: 22-28.

Sutherland, W.J., 2006. Ecological census techniques - a handbook. Cambridge University Press.

Ter Braak, C.J.F., Šmilauer, P., 2012. Canoco reference manual and user's guide: software for ordination, version 5.0. Microcomputer Power, Ithaca, USA.

Thirgood, J.V., 1981. Man and the Meditteranean forest - a history of resource depletion. Academic Press, London.

Touihri, M., Charfi, F., Villard, M-A., 2017. Effects of landscape composition and native oak forest configuration on cavitynesting birds of North Africa. Forest Ecology and Management, 385: 198-205.

Waters, J.R., Noon, B.R., Verner, J., 1990. Lack of nest site limitation in a cavity-nesting bird community. The Journal of Wildlife Management, 54: 239-245.

Wesołowski, T., 2007. Lessons from long-term hole-nester studies in a primeval temperate forest. Journal of Ornithology, 148: 395-405.

Wiebe, K.L., 2011. Nest sites as limiting resources for cavitynesting birds in mature forest ecosystems: a review of the evidence. Journal of Field Ornithology, 82: 239-248. 